\title{
Locomotion and foraging strategy in foot-propelled and wing-propelled shallow-diving seabirds
}

\author{
Akiko Kato ${ }^{1, *}$, Yan Ropert-Coudert ${ }^{1}$, David Grémillet ${ }^{2}$, Belinda Cannell ${ }^{3}$ \\ ${ }^{1}$ National Institute of Polar Research, 1-9-10, Kaga, Itabashi, Tokyo 173-8515, Japan \\ ${ }^{2}$ Centre d'Ecologie et Physiologie Energétiques, CNRS, 23 rue Becquerel, 67087 Strasbourg Cedex 02, France \\ ${ }^{3}$ Murdoch University, South St, Murdoch, Perth 6150, Australia
}

\begin{abstract}
Buoyancy is a major determinant of locomotory cost in diving animals. As seabirds have a large amount of air in their feathers and respiratory system, they should work hard against buoyancy to descend in the water column. Since buoyancy decreases with increasing hydrostatic pressure, shallow divers, especially, should work against buoyancy during both the descent and bottom phases of their dives. We deployed miniaturised depth and acceleration recorders on freeranging, foot-propelled divers (great cormorants Phalacrocorax carbo) and flipper-propelled divers (little penguins Eudyptula minor) foraging in shallow waters, where both are positively buoyant. We monitored the diving strategies of the birds to assess how they manage to counteract buoyancy using 2 alternative locomotory modes. Cormorants decreased the stroke frequency and surge amplitude during descent and maintained constant swim speed. In contrast, penguins did not change their stroke frequency or heave amplitude; as a result, their swim speed increased during the descent phase. During the bottom phase, cormorants had a low stroke frequency and tilted towards the bottom, while penguins actively stroked in a horizontal position. Furthermore, intensive acceleration periods during the bottom phase were often recorded for penguins, but rarely for cormorants. Great cormorants and little penguins used different strategies to feed underwater. Great cormorants, having lower specific buoyancy, were less active than little penguins, thus adopting an energysaving strategy. We conclude that both foot- and wing-propelled birds diving in shallow waters have developed efficient locomotory strategies to counteract buoyancy, these alternative characteristics being linked to different foraging niches.
\end{abstract}

KEY WORDS: Diving $\cdot$ Buoyancy $\cdot$ Seabirds $\cdot$ Locomotory mode $\cdot$ Stroke frequency $\cdot$ Little penguin $\cdot$ Great cormorant

Resale or republication not permitted without written consent of the publisher

\section{INTRODUCTION}

Buoyancy is a major determinant of the locomotory cost in diving animals. For instance, loggerhead turtles Carreta carreta remain at a particular depth by maintaining neutral buoyancy in order to save energy for egg maturation (Minamikawa et al. 2000). Similarly, deep-diving penguins regulate the volume of air that they inhale according to their expected maximum dive depth, and use buoyancy to ascend passively, thereby reducing diving costs (Sato et al. 2002).
When seabirds descend in the water column, work against buoyancy becomes minimal below the depth at which the air spaces in the body have been largely compressed. In the case of a $1 \mathrm{~kg}$ guillemot (Uria spp.), buoyancy decreases rapidly from 0 to $20 \mathrm{~m}$ and becomes negative below $62 \mathrm{~m}$ (Lovvorn et al. 1999). Wilson et al. (1992) demonstrated that energy expenditures of diving birds are maximal just below the water surface, but decrease with increasing depth, rapidly at first, until ca. $20 \mathrm{~m}$, and more slowly afterwards. In the case of deep divers, once animals dive beyond the depth where their buoyancy is minimal, energy is only 
spent for searching, capturing and manipulating prey. In contrast, shallow divers remain in the zone of maximal buoyancy and, therefore, should work against buoyancy during their entire dive cycle, including the descent and bottom phases of their dives.

Despite this apparent handicap, numerous diving birds forage in shallow water to target prey (Furness \& Monaghan 1987). This is because bentho-pelagic coupling is strongest in shallow-water ecosystems (Marcus \& Boero 1998). This phenomenon triggers enhanced primary and secondary productivity, so that food for seabirds becomes particularly abundant in these zones.

Avian predators operating in coastal waters have developed 4 different feeding techniques (Ashmole 1971): (1) surface or sub-surface feeding (gulls, most pelicans, etc.), which is a way to totally bypass most problems linked to diving; (2) plunge-diving (gannets and terns); (3) foot-propelled diving (cormorants, diving ducks and grebes); and (4) wing-propelled diving (penguins and alcids). These foraging techniques are all influenced by, among others, the buoyancy of the birds, i.e. the birds need different ways of dealing with this issue. These different techniques are also linked to specific diets and, therefore, to specific foraging niches.

Penguins are flightless birds, having lost the characteristic adaptations for flight. Their denser, heavier body is particularly adapted to aquatic locomotion, and they are outstanding, breath-holding divers. For instance, the largest emperor penguin, Aptenodytes forsteri (ca. $25 \mathrm{~kg}$ ), can dive up to $535 \mathrm{~m}$ deep (Kooyman \& Kooyman 1995) and even the little penguin Eudyptula minor, the smallest among the Spheniscidae (ca. $1 \mathrm{~kg}$ ), has been recorded to dive as deep as $69 \mathrm{~m}$ (Montague 1984). It should be noted, however, that little penguins reach these extreme depths only occasionally and most of their diving is done at shallower depths (Ropert-Coudert et al. 2003). While penguins became extraordinary divers at the expense of flight ability, cormorants should be regarded as equally impressive divers, since they simultaneously retain the capacity to fly and show high diving capability (Croxall et al. 1991, Kato et al. 2000). This partly results from the wettability of their plumage, a feature that reduces buoyancy, but incurs high energy expenditure, especially when they are immersed in cold waters (Grémillet et al. 2005). As a consequence of this, cormorants at high latitudes minimise the time spent in water and the associated high thermoregulatory cost (Grémillet et al. 2001). Similarly to little penguins, great cormorants Phalacrocorax carbo preferentially exploit shallow waters $(<30 \mathrm{~m})$ (Grémillet et al. 1999). The preferential use of shallow waters by great cormorants and little penguins means that they remain highly buoyant during foraging (Wilson et al. 1992) and they should, therefore, work hard against buoyancy, at least during the descent and bottom phases of their dives.

Penguins and cormorants show one major difference in their locomotory mode: cormorants thrust with their feet, while penguins use their transformed wing (flipper) to swim underwater. Energy costs of foot-propulsion are thought to be much higher than those of wing (flipper)-propulsion (Lovvorn \& Liggins 2002). Until recently, very few studies have investigated the swimming behaviour of these small birds in the wild, so there is only limited information about how foot- and wing-propulsion condition the diving behaviour of these animals. In the present study, we deployed miniaturised, high-precision accelerometers on footpropelled divers (great cormorants) and flipperpropelled divers (little penguins) foraging in shallow waters, to monitor their diving strategies and determine how these birds manage to swim against buoyancy using these 2 alternative locomotory modes.

\section{MATERIALS AND METHODS}

Great cormorants Phalacrocorax carbo carbo rearing small chicks (during the first week after hatching) were caught on their nests at Qeqertaq $\left(69^{\circ} 30^{\prime} \mathrm{N}\right.$, $54^{\circ} 05^{\prime} \mathrm{W}$ ) in the Diskofjord area, Disko, west Greenland, between June and July 2002. Little penguins Eudyptula minor novaehollandiae, also rearing small chicks, were captured in wooden nest-boxes (see Klomp et al. 1991) where they normally breed at Penguin Island $\left(32^{\circ} 16^{\prime} \mathrm{S}, 115^{\circ} 21^{\prime} \mathrm{E}\right)$, Rockingham, Western Australia, in August 2001 and 2002.

The diving behaviour, body posture and swimming activity of birds were monitored using cylindrically shaped data loggers with domed heads (M190-D2GT, Little Leonardo, Tokyo) that weighed $16 \mathrm{~g}(15 \times 52 \mathrm{~mm})$ and had a 128 Mbit flash memory into which data were stored with 12 bit resolution. Depth was measured by a piezoresistive pressure sensor (FPBS-82A, Fujikura, Tokyo) up to $190 \mathrm{~m}$, with a precision of $\pm 1 \mathrm{~m}$ and a resolution of $0.05 \mathrm{~m}$. Acceleration was measured along perpendicular axes by a capacitive accelerometer (ADXL202E, Analog Devices) between 0 and $\pm 30 \mathrm{~m}$ $\mathrm{s}^{-2}$. This sensor measures both dynamic (e.g. vibration) and static accelerations (e.g. gravity). Values recorded by loggers were converted into acceleration with linear regression equations. To obtain the calibration equations, values recorded by each logger set at $90^{\circ}$ and $-90^{\circ}$ from the horizon were regressed on the corresponding acceleration (9.8 and $-9.8 \mathrm{~m} \mathrm{~s}^{-2}$, respectively). In our study, loggers were attached to the lower backs of birds with waterproof TESA tape. Accelera- 
tion signals were measured along the surging (along the main body axis of birds) and heaving (dorsoventrally) axes. Data were recorded at frequencies of $1 \mathrm{~Hz}$ for depth and $16 \mathrm{~Hz}$ on each acceleration axis.

Birds were recaptured at the colony after 1 or $2 \mathrm{~d}$ of deployment, and loggers and TESA tape were retrieved. The status of the birds was checked regularly for several days following the retrieval of the equipment, and birds continued to breed normally after the logger had been removed. Data were downloaded into a PC and analysed using a custom-written macroprogram in IGOR Pro (WaveMetrics, Version 5.03J). The acceleration recorded by the loggers could be separated into that due to gravity and that due to body movements. The high-frequency components of heave and surge accelerations were used to count stroke cycle frequency. Wing-propelled penguins are known to produce a forward thrust during both the upstroke and downstroke (Bannasch 1995). This means that the body of penguins accelerates forward and upward during the downstroke and forward and downward during the upstroke. Therefore, during a single stroke by penguins, the loggers recorded 2 positive peaks on the surge axis (bird moving forward) and 1 positive peak (bird moving upward) and 1 negative peak (bird moving downward) on the heave axis (Watanuki et al. 2003). In foot-propelled cormorants, the body accelerates downward and forward during the power stroke and decelerates during the glide and recovery stroke (Ribak et al. 2004). During the power stroke, 1 positive peak was recorded in surge acceleration and 1 negative peak in heave acceleration (Watanuki et al. 2005). To obtain the stroke frequency, the numbers of positive peaks per second in heave acceleration and surge acceleration were counted for penguins and cormorants, respectively. We assumed that the amplitudes of the heave and surge accelerations reflected the intensity of the strokes in penguins and cormorants, respectively. Body angle was calculated from the surge acceleration for both species, after removing the highfrequency component of the acceleration signal by applying a 2-band, low-pass filter $(0.5 / 1.0 \mathrm{~Hz})$ to the data (IFDL, WaveMetrics, Version 4) and correcting for the angle of logger attachment on the bird's body. Logger attachment angle along the bird's body axis was measured for each bird from the surge acceleration when the bird was on the water surface, and the body axis should be horizontal (Watanuki et al. 2003). Body angle was re-sampled at $1 \mathrm{~Hz}$ and swim speed $(v)$ was calculated using depth change rate $r_{n}=\left(d_{n}-\right.$ $\left.d_{n-1}\right) /\left(t_{n}-t_{n-1}\right)$ (where $d$ is depth and $t$ is time) over $1 \mathrm{~s}$ and the body angle $(\theta)$ following:

$$
v=r / \sin \theta
$$

This calculation assumes that the bird's swimming direction (dive angle) is along the longitudinal (head-tail) axis of the bird (body angle). We calculated swim speed only during the descent phase, because depth change rate was close to zero during the bottom phase and the body angle was not necessarily equal to the dive angle during the ascent phase. For each dive, dive depth, dive duration and bottom time (duration of bottom phase) were calculated. Only dives deeper than $1 \mathrm{~m}$ were considered for analysis. Start and end of bottom phases were defined as the first and last time the depth change rate became $<0.25 \mathrm{~m} \mathrm{~s}^{-1}$ during a dive. Average body angle, stroke frequency and amplitude were calculated for each phase of the dives. Average swim speed during the descent phase was also calculated. Statistical tests were conducted using JMP (SAS Institute, Version 5.1.1J) and StatView (SAS Institute, Version 5.0J). A total of 2792 dives $>1 \mathrm{~m}$ were recorded on 6 male and 6 female great cormorants, and 2121 dives on 3 male and 1 female little penguins (Table 1). Data from males and females in each species were combined, because no significant sex-related differences were found in dive depth or duration for great cormorants and sample size was too small for little penguins. Summary statistics of diving parameters were computed for each species using individual birds as the sampling unit. Averages are provided $( \pm \mathrm{SD})$. All data on stroke frequency, amplitude and swim speed from individuals were pooled and their relationship with depth tested.

Because air volume in the respiratory system and plumage changes with hydrostatic pressure, buoyancy decreases with increasing depth (Lovvorn \& Jones 1991, Wilson et al. 1992). Buoyancy $F_{\text {UP }}$ was calculated as a function of depth $d$ using the equation from Wilson et al. (1992):

$$
F_{\mathrm{UP}}=\rho g\left[\frac{p_{\mathrm{S}}\left(V_{\mathrm{LS}}+V_{\mathrm{FS}}\right)}{p_{\mathrm{s}}+\rho g d}+V_{\mathrm{T}}\right]-g m
$$

where $\rho$ is the density of the seawater $\left(1.025 \times 10^{3} \mathrm{~kg}\right.$ $\mathrm{m}^{-3}$ at $20^{\circ} \mathrm{C}$ for little penguins and $1.028 \times 10^{3} \mathrm{~kg} \mathrm{~m}^{-3}$ at $5^{\circ} \mathrm{C}$ for great cormorants; Fofonoff \& Millard 1983), $g$ is the gravitational acceleration $\left(9.807 \mathrm{~m} \mathrm{~s}^{-2}\right), p_{\mathrm{s}}$ is the atmospheric pressure $\left(1.01 \times 10^{5} \mathrm{~Pa}\right), V_{\mathrm{LS}}$ is the volume of air in the respiratory system at the surface $\left(1.61 \times 10^{-4} \mathrm{~m}^{0.91} \mathrm{~m}^{3}\right.$; Lasiewski \& Calder 1971$), V_{\mathrm{FS}}$ is the volume of air in the feathers at the surface $(3.95 \times$ $10^{-4} \mathrm{~m}^{3}$ for little penguins; Hansen \& Ricklefs 2004; $3.71 \times 10^{-4} \mathrm{~m}^{3}$ for male great cormorants and $3.47 \times$ $10^{-4} \mathrm{~m}^{3}$ for female great cormorants; Grémillet et al. $1998), V_{\mathrm{T}}$ is the volume of the remaining body tissue $\left[\mathrm{m} /\left(1.02 \times 10^{3}\right) \mathrm{m}^{3}\right.$ for penguins and $\mathrm{m} /\left(1.01 \times 10^{3}\right) \mathrm{m}^{3}$ for great cormorants; Wilson et al. 1992] and $m$ is the mass of the bird $(1.28 \mathrm{~kg}$ for little penguins; present 
study; $3.24 \mathrm{~kg}$ for male great cormorants and $2.63 \mathrm{~kg}$ for female great cormorants; Grémillet et al. in press). Mass-specific buoyancy was calculated as $F_{\mathrm{UP}} / m$ $\left(\mathrm{N} \mathrm{kg}^{-1}\right)$.

\section{RESULTS}

Mean dive depth, dive duration and bottom time were $5.98 \pm 1.78 \mathrm{~m}(\max .33 .2 \mathrm{~m}), 18.9 \pm 3.7 \mathrm{~s}$ (max. $75 \mathrm{~s}$ ) and $10.2 \pm 3.1 \mathrm{~s}(\max .45 \mathrm{~s})$ for great cormorants and $10.4 \pm 1.85 \mathrm{~m}$ (max. $22.1 \mathrm{~m}), 37.2 \pm 5.7 \mathrm{~s}(\max .87 \mathrm{~s})$ and $21.7 \pm 5.8 \mathrm{~s}$ (max. $67 \mathrm{~s}$ ) for little penguins (Table 1, Fig. 1). Bottom time accounted for $47.1 \pm 11.6 \%$ (max. $96.3 \%$ ) of the dive duration of great cormorants and $53.1 \pm 8.7 \%(\max .96 .7 \%$ ) of that of little penguins.

Mean stroke frequency of great cormorants was highest during the descent phases $(3.09 \pm 0.15$ strokes $\left.\mathrm{s}^{-1}\right)$, intermediate during the bottom phases $(2.19 \pm$ 0.15 strokes $\mathrm{s}^{-1}$ ) and lowest during the ascent phases of dives $\left(0.87 \pm 0.16\right.$ strokes $\mathrm{s}^{-1}$, ANOVA, $F=363, \mathrm{p}<$ 0.001). In addition, the mean surge amplitude was greater during the descent phase $\left(5.96 \pm 0.46 \mathrm{~m} \mathrm{~s}^{-2}\right)$
Table 1. Phalacrocorax carbo, Eudyptula minor. Sex (M: male, F: female), body mass at deployment, number of dives $(\mathrm{N})$, dive depth, dive duration and bottom time for each bird

\begin{tabular}{|lccccc|}
\hline $\begin{array}{l}\text { No. } \\
\text { sex }\end{array}$ & $\begin{array}{c}\text { Mass } \\
(\mathrm{kg})\end{array}$ & $\mathrm{N}$ & $\begin{array}{c}\text { Depth } \\
(\mathrm{m})\end{array}$ & $\begin{array}{c}\text { Duration } \\
(\mathrm{s})\end{array}$ & $\begin{array}{c}\text { Bottom } \\
\text { time (s) }\end{array}$ \\
\hline \multicolumn{3}{l}{ Great cormorant } \\
1, M & - & 221 & 8.41 & 22.6 & 9.9 \\
2, M & - & 122 & 5.99 & 18.9 & 9.5 \\
3, M & - & 208 & 8.99 & 22.2 & 9.0 \\
4, M & - & 117 & 5.53 & 15.6 & 7.2 \\
5, M & - & 245 & 3.43 & 13.0 & 8.0 \\
6, M & - & 147 & 6.39 & 17.8 & 8.6 \\
1, F & - & 196 & 6.51 & 22.2 & 12.8 \\
2, F & - & 264 & 4.62 & 20.4 & 14.5 \\
3, F & - & 172 & 6.97 & 25.7 & 16.9 \\
4, F & - & 523 & 3.19 & 15.7 & 11.4 \\
5, F & - & 400 & 4.79 & 16.1 & 8.5 \\
6, F & - & 177 & 6.92 & 16.6 & 6.3 \\
Little penguin & & & & \\
18, M & 1.47 & 452 & 12.84 & 31.3 & 14.2 \\
19, M & 1.30 & 428 & 10.72 & 44.9 & 28.3 \\
35, M & 1.45 & 548 & 8.88 & 35.5 & 21.3 \\
65, F & 0.90 & 693 & 9.01 & 37.1 & 22.8 \\
\hline
\end{tabular}

\section{Great cormorant}
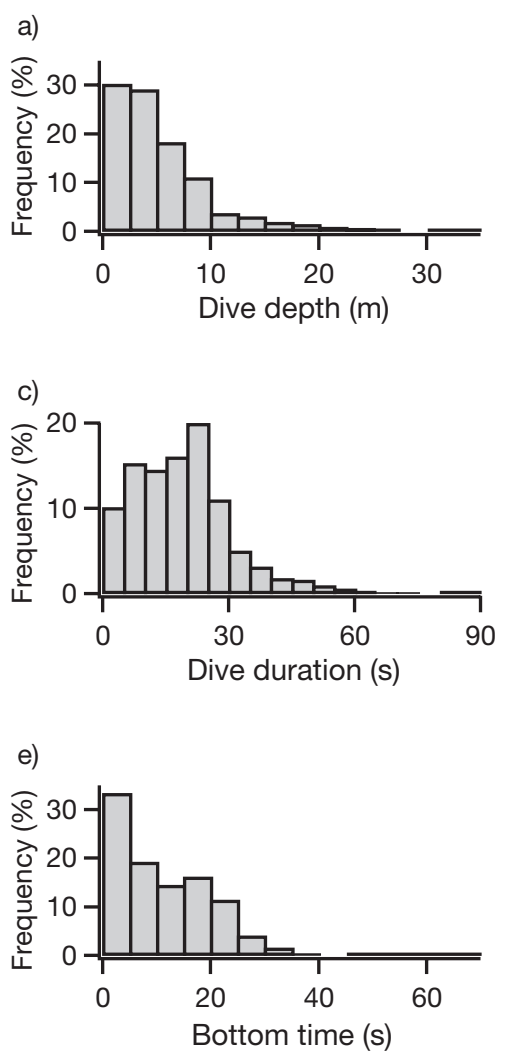

Little penguin

b)
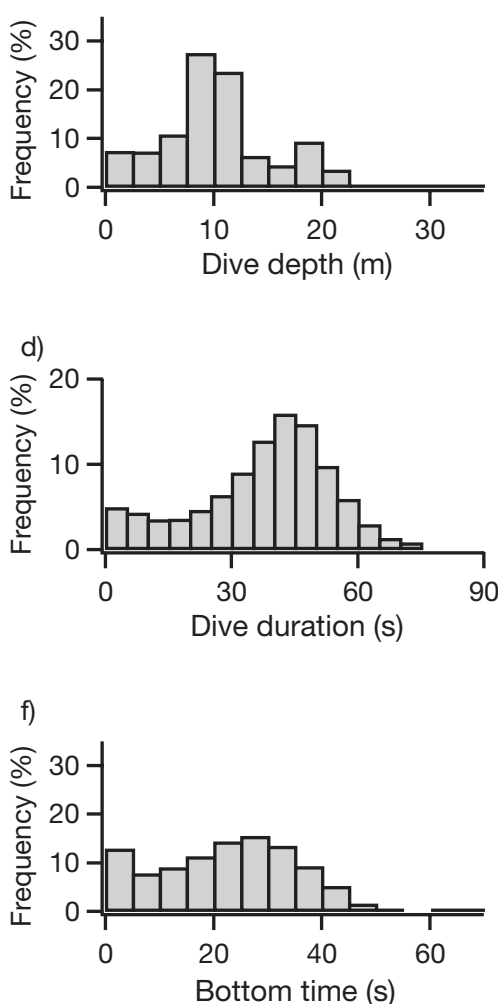

Fig. 1. Phalacrocorax carbo, Eudyptula minor. Frequency distributions of dive depth, duration and bottom time of great cormorant $(\mathrm{a}, \mathrm{c}, \mathrm{e})$ and little penguin $(b, d, f)$. All dives from individuals were pooled

than that during the bottom (4.21 \pm $0.29 \mathrm{~m} \mathrm{~s}^{-2}$ ) and ascent phases (4.21 \pm $0.29 \mathrm{~m} \mathrm{~s}^{-2}$, ANOVA, $\left.F=95.5, \mathrm{p}<0.001\right)$. In contrast, mean stroke frequency and heave amplitude of little penguins were similar during the descent (3.25 \pm 0.25 strokes $\left.\mathrm{s}^{-1}, 5.71 \pm 0.45 \mathrm{~m} \mathrm{~s}^{-2}\right)$ and bottom phases $\left(3.12 \pm 0.25\right.$ strokes $\mathrm{s}^{-1}$, $5.61 \pm 0.54 \mathrm{~m} \mathrm{~s}^{-2}$ ), and lowest during the ascent phase $\left(0.80 \pm 0.28\right.$ strokes $\mathrm{s}^{-1}$, ANOVA, $F=109, \mathrm{p}<0.001 ; 4.12 \pm$ $0.43 \mathrm{~m} \mathrm{~s}^{-2}$, ANOVA, $F=14.2, \mathrm{p}<0.01$ ).

Great cormorants stroked intensively at the beginning of the dive, but both the stroke frequency and surge amplitude gradually decreased with increasing depth during the descent phase (Figs. 2a \& 3a,c, Spearman rank correlation, stroke frequency: $z=-49.7, \mathrm{p}<0.001$, surge amplitude: $z=-27.0, p<0.001$ ). Their swim speed throughout the descent phase remained constant at $1.41 \pm$ $0.11 \mathrm{~m} \mathrm{~s}^{-1}$, irrespective of depth change (Fig. 3e). In contrast, little penguins stroked at a constant frequency and maintained a constant heave amplitude throughout the descent phase, irrespective of depth change (Figs. 2b \& 3b,d), but their swim speed increased with increasing depth (Fig. 3f, Spearman rank correlation, $z=34.0, \mathrm{p}<0.001)$. Average 

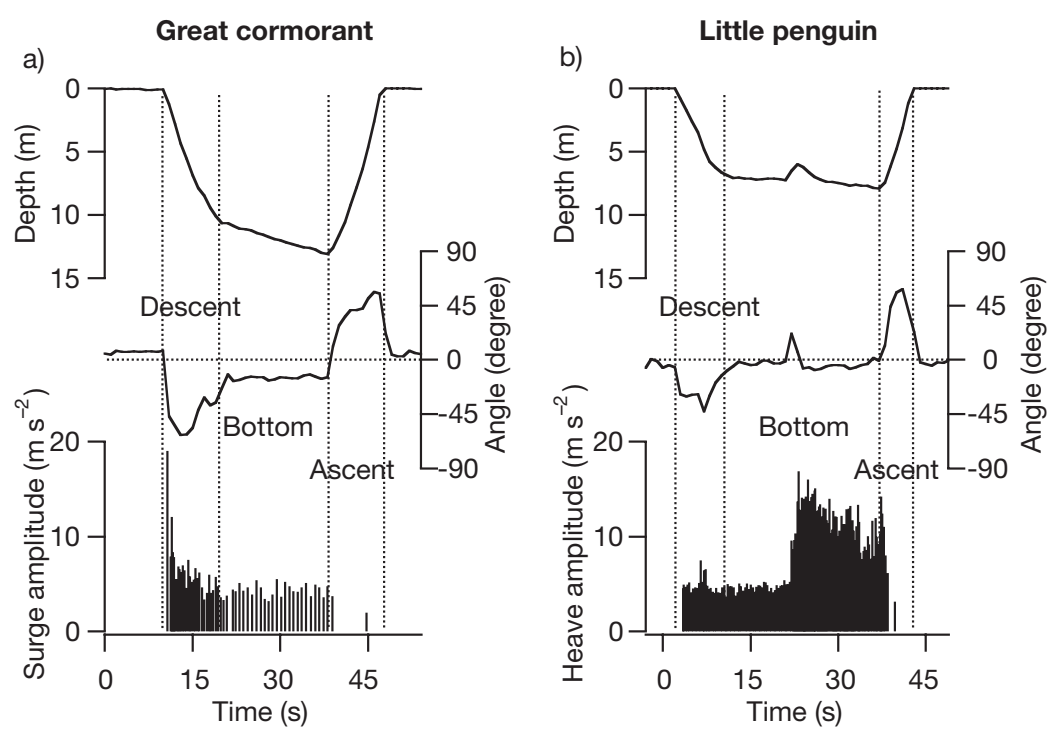

Fig. 2. Phalacrocorax carbo, Eudyptula minor. Variations in body angle and surge or heave amplitude of strokes during a single dive of (a) a great cormorant and (b) a little penguin
Great cormorant
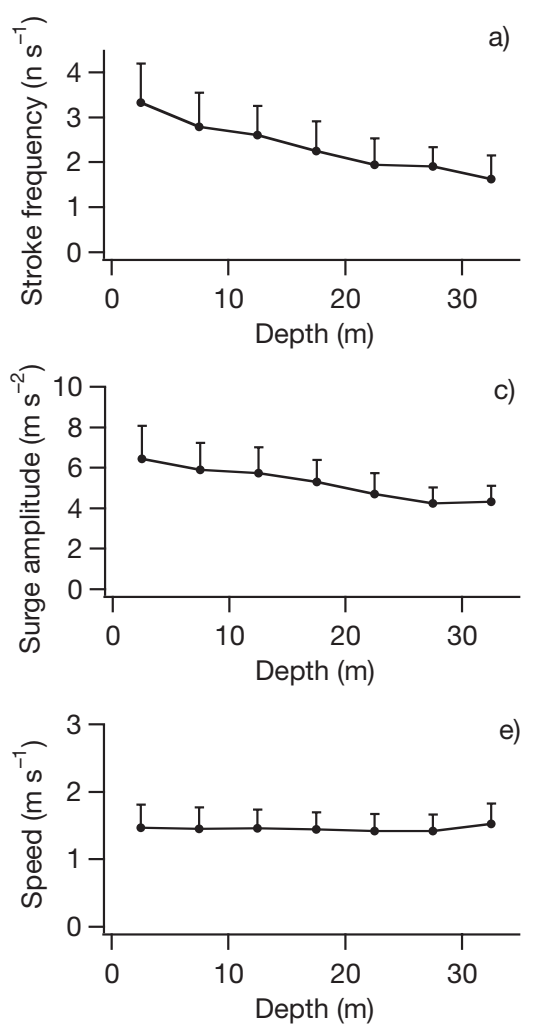

Little penguin

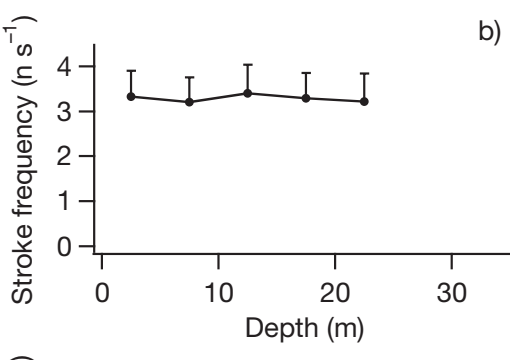

)
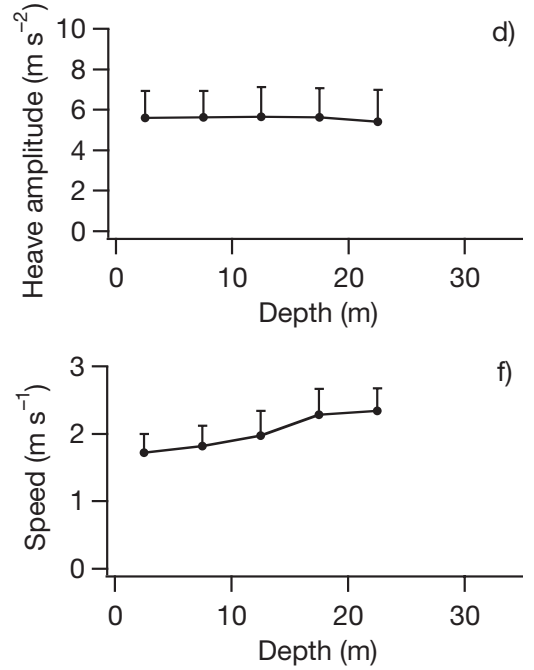

Fig. 3. Phalacrocorax carbo, Eudyptula minor. Mean stroke frequency, surge or heave amplitude and mean swim speed in relation to depth during the descent phase of great cormorants $(\mathrm{a}, \mathrm{c}, \mathrm{e})$ and little penguins $(\mathrm{b}, \mathrm{d}, \mathrm{f})$. Data points represent average values with standard deviation in each depth category every $5 \mathrm{~m}$ swim speed during the descent phase was $1.81 \pm 0.17 \mathrm{~m} \mathrm{~s}^{-1}$.

Mean stroke frequency during the bottom phase was lower for deeper dives, and the mean surge amplitude did not change according to the dive depth for great cormorants (Fig. 4a,c). Though mean stroke frequency and mean heave amplitude during the bottom phase significantly increased with increasing dive depth for little penguins, the relationships were not clear (Fig. 4b,d). Body angle significantly increased with increasing dive depth for both species (Fig. 4e,f). Mean body angle during the bottom phase was $-13.5 \pm 6.3^{\circ}$ for great cormorants and $1.8 \pm 4.8^{\circ}$ for little penguins. In other words, during this phase of dives cormorants were heading principally downward, paddling less frequently $\left(2.19 \pm 0.15\right.$ strokes $\left.\mathrm{s}^{-1}\right)$, while little penguins were almost horizontal, flapping constantly and regularly (3.12 \pm 0.25 strokes s$^{-1}$ ) (Fig. 2). Short periods of high stroke frequency and amplitude were occasionally observed during the bottom phase (Fig. 2b). Strokes with high amplitude ( $>2$ times average amplitude during the bottom phase) were observed in $21.1 \pm 8.4 \%$ of the dives, with $1.9 \pm 0.4$ strokes dive ${ }^{-1}$ (max. 11 strokes dive $^{-1}$ ) for great cormorants, and in $30.1 \pm 6.2 \%$ of the dives, with $8.8 \pm 2.9$ strokes dive ${ }^{-1}$ (max. 104 strokes dive ${ }^{-1}$ ) for little penguins.

In both cormorants and penguins, the ascent was mainly passive, with only a few strokes being occasionally recorded $\left(0.87 \pm 0.16\right.$ strokes $\mathrm{s}^{-1}$ for great cormorants, $0.80 \pm 0.28$ strokes $\mathrm{s}^{-1}$ for little penguins), the last stroke occurring sometimes at the deepest point of the dive or close to the surface in some other instances (Fig. 5).

The calculated specific buoyancy at the water surface according to Eq. (2) was lowest for the male great cormorant $\left(2.8 \mathrm{~N} \mathrm{~kg}^{-1}\right)$, middle for the female great cormorant (3.1 $\mathrm{N} \mathrm{kg}^{-1}$ ) and highest for the little penguin $\left(4.7 \mathrm{~N} \mathrm{~kg}^{-1}\right)$ and decreased to $1 \mathrm{~N} \mathrm{~kg}^{-1}$ at 21 and $25 \mathrm{~m}$ for the male and female great cormorants and $39 \mathrm{~m}$ for the little penguin (Fig. 6). 
Great cormorant
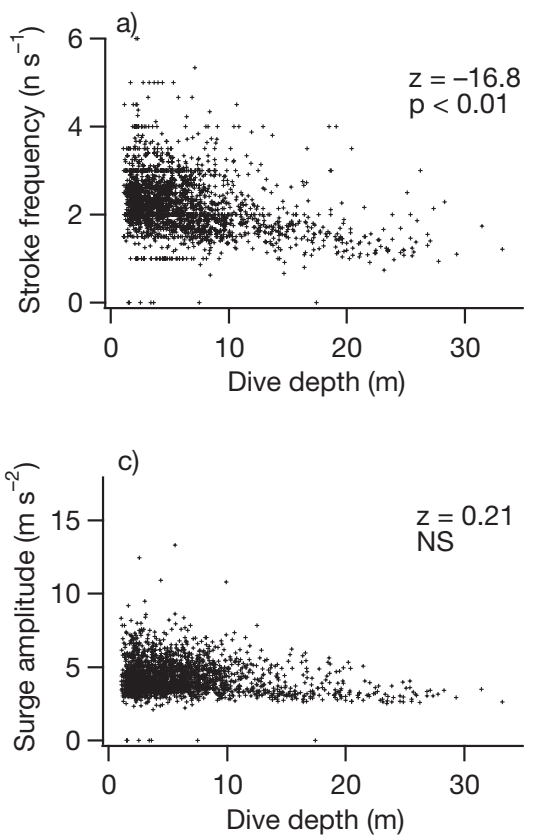

e)

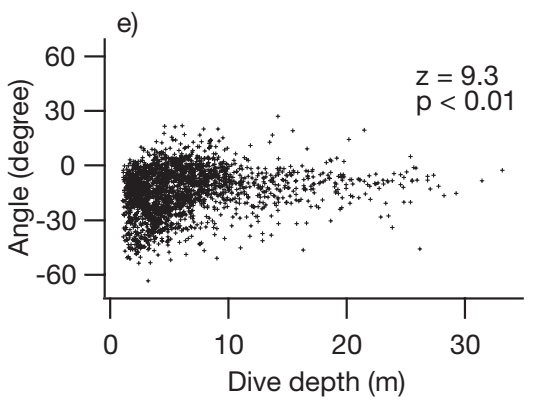

Little penguin
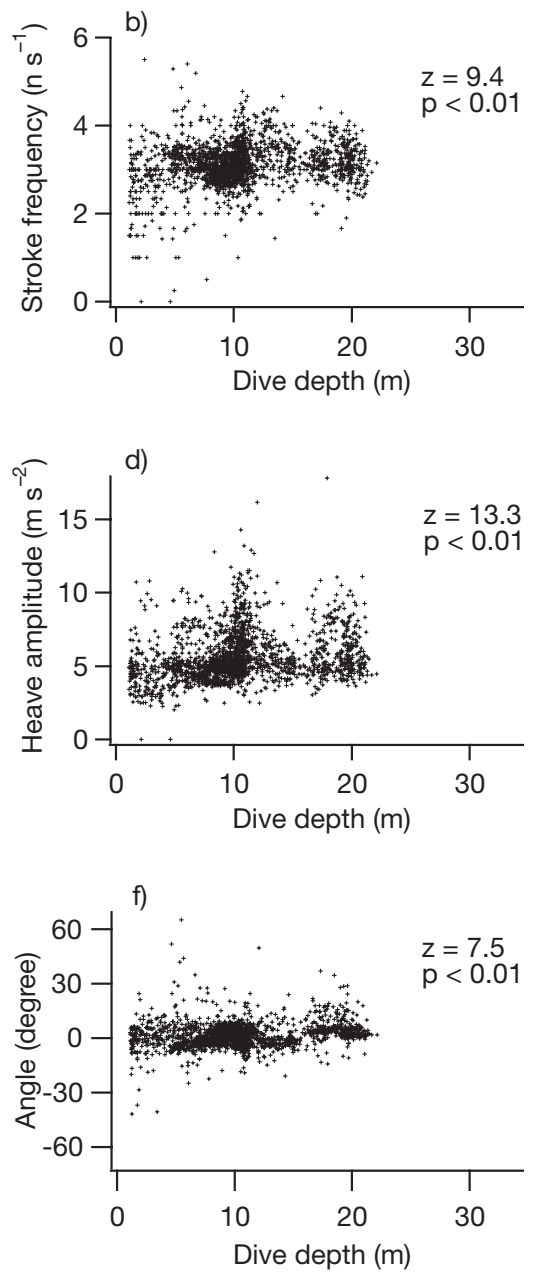

Fig. 4. Phalacrocorax carbo, Eudyptula minor. Mean stroke frequency, surge or heave amplitude and dive angle during the bottom phase in relation to dive depth of great cormorants $(a, c, e)$ and little penguins $(b, d, f)$. Results of Spearman rank correlation tests are shown

a)

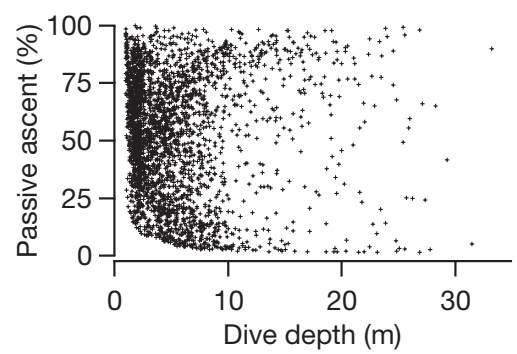

Little penguin

b)

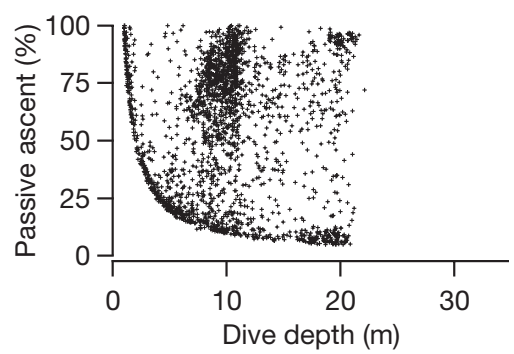

Fig. 5. Phalacrocorax carbo, Eudyptula minor. Proportion of the passive ascent (the depth at which the last stroke occurred divided by the maximum depth reached during dives) in relation to the dive depth of (a) great cormorants and (b) little penguins

\section{DISCUSSION}

In our study, great cormorants Phalacrocorax carbo and little penguins Eudyptula minor spent most of their time in waters shallower than $20 \mathrm{~m}$, stroked intensively against buoyancy while descending in the water column, and ascended passively (at least throughout most of the ascent phase) without stroking because of their positive buoyancy. This suggests that both species were positively buoyant at their preferred diving depths, but that they were exposed to drastic changes in buoyancy during diving. Foot-propelled great cormorants and wing-propelled little penguins dealt with these constraints in different ways, which are linked to contrasting foraging niches.

\section{Descent phase}

Great cormorants decreased both stroke frequency and intensity during the descent phase and maintained a constant swim speed $\left(1.4 \mathrm{~m} \mathrm{~s}^{-1}\right)$, which was lower than the speed at minimum cost of transport $\left(\mathrm{COT}_{\min }\right)$ measured in a water canal $\left(1.9 \mathrm{~m} \mathrm{~s}^{-1}\right.$ at $19.1 \mathrm{~J} \mathrm{~kg}^{-1} \mathrm{~m}^{-1}$; Schmid et al. 1995). Diving birds should control their swimming performance and maintain their swim speeds within a narrow range if they are to minimise the drag coefficient, because drag increases exponentially with increasing speed (Lovvorn et al. 1999). Similarly, emperor penguins, Magellanic penguins Spheniscus magellanicus and bottlenose dolphins Tursiops truncatus decrease their stroke frequency and/or intensity with increasing depth (Skrovan et al. 1999, van Dam et al. 2002, Wilson \& Liebsch 2003, Wilson \& Zimmer 2004). In addition, Adélie Pygoscelis adeliae (RopertCoudert et al. 2002) and Magellanic penguins (Wilson \& Zimmer 2004) descend at constant speeds, like the great cormorants in our study.

It is, therefore, surprising that little penguins did not change their stroke 


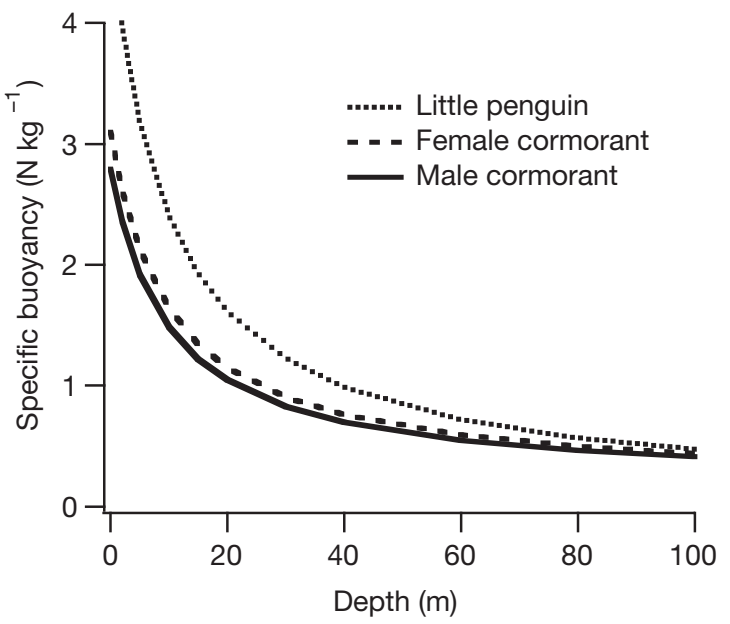

Fig. 6. Phalacrocorax carbo, Eudyptula minor. Change of calculated mass-specific buoyancy in relation to the water depth for male (solid line) and female great cormorants (dashed) and little penguins (dotted). See Eq. (2) in 'Materials and methods'

frequency and intensity and that, as a result, their swim speed increased during the descent from 1.7 to $2.3 \mathrm{~m} \mathrm{~s}^{-1}$. We suggest that little penguins might change their speed during this phase of the dive in order to minimise the cost of transport. The speed at $\mathrm{COT}_{\min }$ determined in captive little penguins swimming in a water canal was $1.8 \mathrm{~m} \mathrm{~s}^{-1}$ at $11.1 \mathrm{~J} \mathrm{~kg}^{-1} \mathrm{~m}^{-1}$ (Bethge et al. 1997), which is close to the swim speed of little penguins near the surface in our study (Fig. 3). Costs of transport are generally measured when birds swim horizontally in shallow water canals, where buoyancy is maximum. However, the cost of transport and speed at $\mathrm{COT}_{\min }$ are expected to change with depth as buoyancy changes. The increase in swim speed recorded during the descent of these birds probably reflected the adjustment of velocity to different levels of buoyancy in order to maintain themselves at a speed corresponding to the $\mathrm{COT}_{\min }$. This situation is similar to that of Brünnich's guillemots Uria lomvia, which also increase their descent speed until ca. $40 \mathrm{~m}$, but without changing the stroke frequency (Watanuki et al. 2003, Lovvorn et al. 2004). As mentioned previously wingpropelled penguins produce a forward thrust during both the upstroke and downstroke (Bannasch 1995). The situation is similar for wing-propelled alcids swimming in shallow waters, but these birds rely only on the downstroke to move forward in deeper waters (Watanuki et al. 2003). Thus, guillemots are able to control surge frequency without changing stroke frequency. In birds like alcids that 'fly' both in air and under water, physiological efficiency of muscle contraction can be maximised only in a relatively narrow range of contraction speeds and loads (Lovvorn et al.
1999). Spheniscid adaptation to aquatic locomotion is most likely a conversion from a procellariid type of flying bird, such as the diving petrel (Simpson 1975). Little penguins branched out early from the other sphenicids, suggesting that they are the closest to the ancestral type among the penguin species (Tsuda et al. 2001). In this regard, we suggest that little penguins optimise the physiological efficiency of muscle contraction by maintaining a constant stroke frequency like alcids do. Little penguins and Brünnich's guillemots are, to our knowledge, the only diving birds that increase their swim speed with decreasing buoyancy. This may relate to the fact that their body size is smaller than that of other diving birds for which underwater velocities are known and that they experience (relatively) higher cost of transport than larger diving animals (Schmidt-Nielsen 1984). Furthermore, size differences could be another factor affecting the stroke pattern during the descent phase. If $V_{\mathrm{LS}}$ scales with $m^{0.91}$ (Lasiewski \& Cadler 1971), then the larger the bird is, the less air it contains in its respiratory tract relative to its mass. Similarly, $V_{\mathrm{FS}}$ should depend on surface area (feathers), which scales roughly with $\mathrm{m}^{0.66}$. As the body density of penguins and cormorants are not very different (Wilson et al. 1992), it can be expected that the larger the bird is, the less surface it has and the less $V_{\text {FS }}$ per kilogram body mass. Therefore, the specific buoyancy should be greater for smaller animals.

\section{Bottom phase}

Little penguins maintain a horizontal position and actively stroke throughout the bottom phase, presumably to prevent themselves from floating back to the surface. In contrast, great cormorants did not stroke much during the bottom phase, especially in deeper water, and headed towards the bottom. Great cormorants use their feet, situated at the rear end of their bodies, to propel themselves. With such a design, it is preferable for cormorants to be head-down in order to resist buoyant forces and stay at a given depth (Ribak et al. 2004). The constant stroking of little penguins can be explained by the fact that, at any depth, a little penguin has a higher specific buoyancy than a great cormorant (Fig. 6); this situation results from the larger body size and the partial plumage wettability of cormorants (Grémillet et al. 2005), which help them decrease their buoyancy in water.

Besides purely physical aspects, the behaviour of the main prey of cormorants and penguins can also contribute to explaining the results observed in our study. Great cormorants in Greenland feed mainly on bottomdwelling fish, such as the sculpins Gymnacanthus 
tricuspis and Myoxocephalus scorpioides and occasionally on capelins Mallotus villosus and gadids Gadus sp. in coastal areas (Grémillet et al. 2004). Penguins from Penguin Island feed mainly on the sprats Hyperlophus vittatus and Spratelloides robustus, southern sea garfish Hyporhamphus melanochir and pilchards Sardinops neopilchardus, mainly within $5 \mathrm{~km}$ of their colony, in shallow waters where the maximum depth is about $17 \mathrm{~m}$ (Klomp \& Wooller 1988). This accords well with the dive depth of little penguins in our study, which ranged mainly between 5 and $15 \mathrm{~m}$ and with the fact that the birds' dive profiles were typical bottom-feeding dives, with long, flat bottom phases (Tremblay \& Cherel 2000). Altogether, this suggests that the little penguins in our study were feeding principally near the seabed. Furthermore, intensive acceleration periods during bottom phases were recorded often in little penguins, but were less frequent in great cormorants. These differences in swimming modes probably result from the fact that cormorants feed on prey that are immobile, burrowed in the sand or hidden under rocks, using a neckstretching strategy (Johnsgard 1993, A. Kato unpubl. data), whereas little penguins feed on more actively swimming, demersal fish that require active pursuit phases (Schulz 1987). These differences in prey behaviour can also explain the main posture adopted during hunting by our birds, i.e. the head-down versus horizontal position of cormorants and penguins, respectively.

Overall, great cormorants are less 'active' underwater (in the sense that they stroke less often) than little penguins, likely adopting an energy-saving strategy. Saving energy would be highly relevant in the case of great cormorants swimming in cold waters, because of the high energy costs of thermoregulation incurred (Grémillet \& Wilson 1999) and the poor prey abundance of their Greenlandic feeding grounds (Grémillet et al. 2004).

We conclude that both foot- and wing-propelled birds diving in shallow water have developed efficient locomotory strategies to counteract buoyancy, but that these characteristics are related to different foraging niches. Maximum dive depths of great cormorants in Greenland in summer and little penguins in Penguin Island are lower than those of the same species from other localities (Montague 1984, Grémillet et al. 2001). Further studies are needed to compare the diving and foraging strategies among colonies in different environments.

Acknowledgements. This study was funded by the Institut Polaire Français Paul-Emile Victor through Grant No. 388 to D.G. and by the Centre National de la Recherche Scientifique, as well as the Japanese Society for Promotion of Science and Murdoch University. The Arctic station in God- havn provided logistics support during the field season on Disko. The experimental procedure on great cormorants was validated by the ethics committee of the French Polar Institute, the Greenland Homerule Government, the Danish veterinary services, the Danish Polar Center, and the science board of the Arctic station. All research in Australia was covered by the appropriate Department of Conservation and Land Management permits. We thank G. Kuntz, M. Mellet, P.-E. Chaillon, as well as M. Mitchell, C. Lamont, M. Banks, T. Goodlich, all the wardens of Penguin Island and the staff from the Penguin Experience on Penguin Island for their help in the field.

\section{LITERATURE CITED}

Ashmole NP (1971) Seabird ecology and marine environment. In: Farner DS, King JR, Parkes KC (eds) Avian biology. Academic Press, New York, p 224-286

Bannasch R (1995) Hydrodynamics of penguins - an experimental approach. In: Dann P, Norman I, Reilly P (eds) The penguins. Surrey, Beatty \& Sons, Berlin, p 141-176

Bethge P, Nicol S, Culik BM, Wilson RP (1997) Diving behaviour and energetics in breeding little penguins (Eudyptula minor). J Zool Lond 242:483-502

Croxall JP, Naito Y, Kato A, Rothery P, Briggs D (1991) Diving patterns and performance in the Antarctic blue-eyed shag Phalacrocorax atriceps. J Zool Lond 225:177-199

Fofonoff P, Millard RC Jr (1983) Algorithms for computation of fundamental properties of seawater. UNESCO Technical Papers in Marine Sciences 44, UNESCO, Paris

Furness RW, Monaghan P (1987) Seabird ecology. Blackie, Glasgow

Grémillet D, Wilson RP (1999) A life in the fast lane: energetics and foraging strategies of the great cormorant. Behav Ecol 10:516-524

Grémillet D, Tuschy I, Kierspel M (1998) Body temperature and insulation in diving great cormorants and European shags. Funct Ecol 12:386-394

Grémillet D, Wilson RP, Storch S, Gary Y (1999) Three-dimensional space utilization by a marine predator. Mar Ecol Prog Ser 183:263-273

Grémillet D, Wanless S, Carss DN, Linton D, Harris MP, Speakman JR, Le Maho Y (2001) Foraging energetics of arctic cormorants and the evolution of diving birds. Ecol Lett 4:180-184

Grémillet D, Kuntz G, Delbart F, Mellet M and 6 others (2004) Linking the foraging performance of a marine predator with local prey abundance. Funct Ecol 18:793-801

Grémillet D, Chauvin C, Wilson RP, Maho YL, Wanless S (2005) Unusual feather structure allows partial plumage wettability in diving great cormorants Phalacrocorax carbo. J Avian Biol 36:57-63

Grémillet D, Wanless S, Boertmann DM, Wilson RP (in press) The relative importance of physiological and behavioural adaptation in diving endotherms: a case study with Arctic cormorants. In: Proceedings of the 23rd International Ornithological Congress, Beijing

Hansen ES, Ricklefs RE (2004) Foraging by deep-diving birds is not constrained by an aerobic diving limit: a model of avian depth-dependent diving metabolic rate. Am Nat 163:358-374

Johnsgard PA (1993) Cormorants, darters, and pelicans of the world. Smithsonian Institute Press, Washington, DC

Kato A, Watanuki Y, Nishumi I, Kuroki M, Shaugnessy P, Naito Y (2000) Variation in foraging and parental behavior of king cormorants. Auk 117:718-730 
Klomp NI, Wooller RD (1988) Diet of little penguins, Eudyptula minor, from Penguin Island, Western Australia. Aust J Mar Freshw Res 39:633-639

Klomp N, Meathrel C, Wienecke BC, Wooller R (1991) Surface nesting by little penguins on Penguin Island, Western Australia. Emu 91:190-193

Kooyman GL, Kooyman T (1995) Diving behavior of emperor penguins nurturing chicks at Coulman Island, Antarctica. Condor 97:536-549

Lasiewski RC, Calder WA (1971) A preliminary allometric analysis of respiratory variables in resting birds. Respir Physiol 11:152-166

Lovvorn JR, Jones DR (1991) Effect of body size, body fat, and change in pressure with depth on buoyancy and costs of diving in ducks (Aythya spp.). Can J Zool 69:2879-2887

Lovvorn JR, Liggins GA (2002) Interactions of body shape, body size and stroke-acceleration patterns in costs of underwater swimming by birds. Funct Ecol 16:106-112

Lovvorn JR, Croll DA, Liggins GA (1999) Mechanical versus physiological determinants of swimming speeds in diving Brunnich's guillemots. J Exp Biol 202:1741-1752

Lovvorn JR, Watanuki Y, Kato A, Naito Y, Liggins GA (2004) Stroke patterns and regulation of swim speed and energy cost in free-ranging Brünnich's guillemots. J Exp Biol 207:4679-4695

Marcus NH, Boero F (1998) Minireview: the importance of benthic-pelagic coupling and the forgotten role of life cycles in coastal aquatic systems. Limnol Oceanogr 43:763-768

Minamikawa S, Naito Y, Sato K, Matsuzawa Y, Bando T, Sakamoto W (2000) Maintenance of neutral buoyancy by depth selection in the loggerhead turtle Caretta caretta. J Exp Biol 203:2967-2975

Montague T (1984) A maximum dive recorder for little penguins. Emu 85:264-267

Ribak G, Weihs D, Arad Z (2004) How do cormorants counter buoyancy during submerged swimming? J Exp Biol 207:2101-2114

Ropert-Coudert Y, Kato A, Baudat J, Sato K, Bost CA, Le Maho Y, Naito Y (2002) Swim speed of free-ranging Adélie penguins, Pygoscelis adeliae, and its relation to the maximum depth of dives. J Avian Biol 33:95-99

Ropert-Coudert Y, Kato A, Naito Y, Cannell B (2003) Individual diving strategies in little penguins Eudyptula minor. Waterbirds 23:406-408

Editorial responsibility: Howard I. Browman (Associate Editor-in-Chief), Storebø, Norway
Sato K, Naito Y, Kato A, Niizuma Y and 5 others (2002) Buoyancy and maximal diving depth in penguins: Do they control inhaling air volume? J Exp Biol 205:1189-1197

Schmid D, Grémillet D, Culik B (1995) Energetics of underwater swimming in the great cormorant (Phalacrocorax carbo sinensis). Mar Biol 123:875-881

Schmidt-Nielsen K (1984) Scaling. Why is animal size so important? Cambridge University Press, Cambridge

Schulz M (1987) Observations of feeding of a little penguin Eudyptula minor. Emu 87:86-187

Simpson GG (1975) Fossil penguins. In: Stonehouse B (ed) The biology of penguins. Macmillan, London, p 19-41

Skrovan RC, Williams TM, Berry P, Moore P, Davis RW (1999) The diving physiology of bottlenose dolphins (Tursiops truncatus). II. Biomechanics and changes in buoyancy at depth. J Exp Biol 202:2749-2761

Tremblay Y, Cherel Y (2000) Benthic and pelagic dives: a new foraging behaviour in rockhopper penguins. Mar Ecol Prog Ser 204:257-267

Tsuda TT, Tsuda M, Naruse T, Kawata H and 7 others (2001) Phylogenetic analysis of penguin (Spheniscidae) species based on sequence variation in MHC Class II genes. Immunogenetics 53:712-716

van Dam RP, Ponganis PJ, Ponganis KV, Levenson DH, Marshall G (2002) Stroke frequencies of emperor penguins diving under sea ice. J Exp Biol 205:3769-3774

Watanuki Y, Niizuma Y, Gabrielsen GW, Sato K, Naito Y (2003) Stroke and glide of wing propelled divers: deep diving seabirds adjust surge frequency to buoyancy change with depth. Proc R Soc Lond B 270:483-488

Watanuki Y, Takahashi A, Daunt F, Wanless S, Harris MP, Sato K, Naito Y (2005) Regulation of stroke and glide in a foot-propelled avian diver. J Exp Biol 208:2207-2216

Wilson RP, Liebsch N (2003) Up-beat motion in swinging limbs: new insights into assessing movement in free-living aquatic vertebrates. Mar Biol 142:537-547

Wilson RP, Zimmer I (2004) Inspiration by Magellanic penguins: reduced swimming effort when under pressure. Mar Ecol Prog Ser 278:303-307

Wilson RP, Hustler K, Ryan PG, Burger AE, Nöldeke EC (1992) Diving birds in cold water: Do Archimedes and Boyle determine energetic costs? Am Nat 140:179-200

Submitted: April 22, 2005; Accepted: October 4, 2005

Proofs received from author(s): January 24, 2006 